\title{
Dealing with Hazing: Are There Different Profiles of Higher Education Students?
}

\section{Osvaldo Dias Lopes Silva ${ }^{1}$, Suzana Nunes Caldeira ${ }^{2}$, Maria Mendes ${ }^{3}$, Susana Botelho ${ }^{4}$, Maria José D. Martins ${ }^{5}$}

ISSN: 2311-8636 (Print)

ISSN: 2312-2021 (Online)

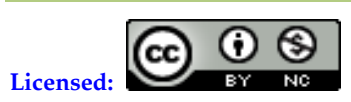

${ }^{1.2}$ University of Azores, CICS.UAc/CICS.NOVA.UAc, Ponta Delgada, PORTUGAL

${ }^{3,4}$ University of Azores, Ponta Delgada, PORTUGAL

${ }^{5}$ Polytechnic Institute of Portalegre, Portalegre, PORTUGAL

Source of Support: Nil

No Conflict of Interest: Declared

Email for correspondence:

osilva@uac.pt

\section{ABSTRACT}

This study aims to understand the kind of relationship that students from two Portuguese higher education institutions - the Portalegre School of Health Sciences (ESSP) and the University of the Azores (UAC) - have with hazing and whether there are profiles of students associated with different types of relationship with hazing. Data were collected through the scale 'Evaluation of Bullying Situations in Higher Education Hazing'. The findings obtained using appropriate statistical techniques, exhibit significant differences between the ESSP and the UAC, with students from the ESSP displaying a better relationship with hazing. They also showcase appreciable differences in the relationship with hazing between the ESSP and the UAC depending on personal, academic and behavioral variables. The findings finally indicate that, at each institution, the profile of students who express a better relationship with hazing differs from those who distance themselves from this ritual in terms of personal, academic and behavioral variables.

Keywords: higher education; hazing practices, students' profiles

\section{INTRODUCTION}

The concept of joint hazing practices is starting to appear today associated to the entry of students to higher education, and it corresponds to situations where veterans and freshmen develop actions in various fields to benefit the community (Mascarenhas, Matos, Jesus \& Galdino, n.d.; Diário Digital/Lusa, 2015). It includes some activities designed to introduce students to their new educational institution based on civic intervention, according to the needs of the surrounding community, and it aims to promote understanding and unity among beginner and experienced students, praising the commitment to defend values such as respect, mutual aid, empathy, altruism and solidarity.

However, the most common reports about hazing in higher education have not particularly placed it in the realm of mutual help among students and of civility in the integration into a higher education establishment. Hazing is more frequently described as an exercise of power of the oldest over the youngest where events that cause 
embarrassment, result in harassment and expose to ridicule or danger situations (Hazing Prevention Organization, 2015; Hoover and Pollard, 2000) appear naturalized.

Therefore, while the premise of familiarization with the new institution seems to be a recurrent theme of hazing practices, there is no consensus among freshmen on whether these initiation rituals are beneficial to their adaption to the new context. However, some of them actually seem to regard hazing as a number of fun activities (Keating, Pomerantz, Pommer, Ritt, Miller and McCormick, 2005) that facilitate the socialisation with peers, activate the sense of belonging to a new group and to a new environment (Dias and Sá, 2013; Vieira, 2013) and help to deal with homesickness, especially for students that are far from their area of residence (Chaleta, 2013). Others seem to believe that, while having unfavourable impacts (Marcitllach and Freire, 2013), hazing is a way to preserve the traditions of the institution as well as to integrate newcomers, assuming that it is the freshmen's duty to live through situations similar to those experience by their older peers (Keating, Pomerantz, Pommer, Ritt, Miller and McCormick, 2005). Other freshmen appear to submit themselves to practices that they admit to being abusive, but probably thanks to their inexperience and desire to feel part of the academy, they minimise the abuse considering it harmless (Marcitllach and Freire, 2013) or the result of occasional excesses of veterans (Klerk 2013).

In line with the need to address the negative feelings that hazing generates, the Hazing Prevention Organization (2015) has alerted to the subtle difference between hazing and bullying, since the dynamics and intimidation strategies involved in both cases are very similar. According to this organisation, the difference lies in that bullying aims to exclude a given individual from the group, while hazing is a ritual for the individual to enter a given group. We would add that this group can take on greater importance, since entering higher education is a transforming experience for many students, a time for personal reevaluation in terms of thoughts, beliefs, goals and values (Coleyshaw, 2010) and for the construction of a personal life project. Given all of these aspects, this research aimed to understand the relationship with hazing of Portuguese students from two different higher education institutions and to uncover any profiles of students associated with the predominant types of relationship with this initiation event.

\section{Methodology}

This study was conducted among 585 Portuguese-higher-education students (nonprobabilistic sampling) and analysed two institutions: the Portalegre School of Health Sciences (ESSP, $n=154,26.3 \%$ ) and the University of the Azores (UAC, $n=431,73.7 \%$ ). Considering the total number of participants, 199 (34\%) are male and 386 (66\%) female. In the subsample of the ESSP, $81.2 \%$ of students are female and $18.8 \%$ male; in the subsample of the UAC, $60.6 \%$ of students are female and $39.4 \%$ male.

Data were collected through a survey that included a section with a personal, academic and behavioural characterisation and the scale Evaluation of Bullying Situations in Higher Education Hazing (SEBSHEH). We considered the personal variables 'gender' (male or female) and 'age group' (coded into two categories: 20 or younger and over 20), the academic variables 'training institution' (ESSP or UAC) and 'year of the degree being attended' $\left(1^{\text {st }}\right.$ year, $2^{\text {nd }}$ year or $3^{\text {rd }}$ year), and the behavioural variables 'joined hazing activities in general' (did not engage, engaged moderately or engaged heavily) and 'joined this year' (did not participate or participated). The SEBSHEH aims to collect data about the type of relationship with hazing and is composed of fifteen self-answer items distributed by three factors (Matos, Jesus, Simões and Nave 2010), as presented in Table 1. 
Table 1: Evaluation Scale of Bullying Situations in Higher Education Hazing - distribution of items by factor

\begin{tabular}{|c|c|c|}
\hline Factor & & Item \\
\hline \multirow{6}{*}{$\begin{array}{c}\text { I } \\
\text { Positive } \\
\text { relationship with } \\
\text { hazing }\end{array}$} & 3 & I am happy when I am hazed \\
\hline & 5 & I believe that hazing contributes to my integration at university \\
\hline & 6 & Those who hazed me like me \\
\hline & 7 & I like to be hazed \\
\hline & 9 & I like to take part in hazing activities \\
\hline & 10 & They respected my wish not to be hazed \\
\hline \multirow{6}{*}{$\begin{array}{c}\text { II } \\
\text { Negative } \\
\text { relationship with } \\
\text { hazing }\end{array}$} & 8 & I cannot wait for hazing activities to end \\
\hline & 11 & Hazing activities included some violence \\
\hline & 12 & I was verbally or physically assaulted \\
\hline & 13 & I was able to cope well with hazing \\
\hline & 14 & I was revolted \\
\hline & 15 & My self-esteem was damaged \\
\hline \multirow{3}{*}{$\begin{array}{c}\text { III } \\
\text { Social dimension }\end{array}$} & 1 & There are rules for those who carry out hazing activities \\
\hline & 2 & I can talk about hazing whenever I deem necessary \\
\hline & 4 & I can count on my family whenever I need \\
\hline
\end{tabular}

To answer the SEBSHEH, each student selected one and only one of five possible answers to each item (1 - Strongly disagree, 2 - Disagree, 3 - Neither agree nor disagree, 4 - Agree, and 5 - Strongly agree). The scores attributed to the negative items $(8,11,12,13,14$ and 15) were inverted (1 - Strongly agree, ..., 5 - Strongly disagree).

To obtain the results of the global scale, we added the scores of the fifteen items; to obtain the results of the factors, we calculated the score of the items that contributed to them. The total score of the SEBSHEH and the score of each of its factors was recorded into three categories (Disagree, Neither agree nor disagree, and Agree), with this information being used in the Multiple Correspondence Analysis. Data were analysed using several statistical methods, especially non-parametric statistical tests (tests: Kolmogorov-Smirnov with Lilliefors correction, Mann-Whitney, Kruskal-Wallis) and Multiple Correspondence Analysis (MCA).

\section{FINDINGS}

Table 2: Mean ranks of the global scale and of the factors of the SEBSHEH by educational institution and significance of the differences observed

\begin{tabular}{|l|c|c|c|}
\hline & \multicolumn{2}{|c|}{ Mean ranks } & $\begin{array}{c}\text { Mann-Whitney (U Test) } \\
\text { Significance of differences }\end{array}$ \\
\hline & ESPP & UAC & \\
\hline Global scale & 294.97 & 249.47 & $\mathrm{U}=22541(\mathrm{p}=0.002)$ Significant \\
\hline Factors & 323.85 & 281.98 & $\mathrm{U}=28436(\mathrm{p}=0.008)$ Significant \\
\hline 1 - Positive relationship with hazing & 312.30 & 286.21 & $\mathrm{U}=30215.5(\mathrm{p}=0.095)$ Not significant \\
\hline 2 - Negative relationship with hazing & 275.91 & 256.72 & $\mathrm{U}=25285(\mathrm{p}=0.192)$ Not significant \\
\hline 3 - Social dimension & 312.09 &
\end{tabular}

Table displays the SEBSHEH findings (total and by factor) according to the institution that students belong to.

The findings indicate that there are significant differences between the students of the ESSP and of the UAC in what concerns the global scale ( $U=22541 ; p=0.002<\alpha=0.05)$ and factor 1 ( $U=28436$; $p=0.008<\alpha=0.05)$, with those from the ESSP exhibiting a better relationship with hazing ( $\mathrm{mgESSP}=294.97$; $\mathrm{mf1ESSP}=323.85$, where $\mathrm{m}$ is the mean ranks). One possible interpretation is that the ESSP students feel that they have fun with hazing 
and that it plays a facilitating role for their integration into the institution. Table 2 presents the SEBSHEH findings according to the institution that students belong to as a function of the other personal, academic and behavioural variables.

Table 3: Test statistic value of the global scale and by factors and significance of the differences observed for each institution

\begin{tabular}{|c|c|c|c|c|c|c|c|c|}
\hline & \multicolumn{4}{|c|}{$E S S P$} & \multicolumn{4}{|c|}{$U A c$} \\
\hline & $\begin{array}{l}\text { Global } \\
\text { scale }\end{array}$ & $\begin{array}{l}\text { Positive } \\
\text { relation }\end{array}$ & $\begin{array}{c}\text { Negative } \\
\text { relation }\end{array}$ & $\begin{array}{c}\text { Social } \\
\text { dimension }\end{array}$ & $\begin{array}{l}\text { Global } \\
\text { scale }\end{array}$ & $\begin{array}{l}\text { Positive } \\
\text { relation }\end{array}$ & $\begin{array}{l}\text { Negative } \\
\text { relation }\end{array}$ & $\begin{array}{c}\text { Social } \\
\text { dimension }\end{array}$ \\
\hline Gender & $\begin{array}{l}U=1186 \\
p=0.044\end{array}$ & $\begin{array}{l}\mathrm{U}=1300 \\
\mathrm{p}=0.018\end{array}$ & $\begin{array}{c}\mathrm{U}=1172.5 \\
\mathrm{p}=0.037\end{array}$ & $\begin{array}{c}\mathrm{U}=15225.5 \\
\mathrm{p}=0.064\end{array}$ & $\begin{array}{c}\mathrm{U}=16684.5 \\
\mathrm{p}=0.665\end{array}$ & $\begin{array}{c}\mathrm{U}=21441 \\
\mathrm{p}=0.555\end{array}$ & $\begin{array}{c}\mathrm{U}=15225.5 \\
\mathrm{p}=0.064\end{array}$ & $\begin{array}{l}\mathrm{U}=22048 \\
\mathrm{p}=0.913\end{array}$ \\
\hline Age group & $\begin{array}{l}\mathrm{U}=2013.5 \\
\mathrm{p}=0.099\end{array}$ & $\begin{array}{l}\mathrm{U}=2584 \\
\mathrm{p}=0.499\end{array}$ & $\begin{array}{l}\mathrm{U}=1765 \\
\mathrm{p}=0.007\end{array}$ & $\begin{array}{c}\mathrm{U}=2616.5 \\
\mathrm{p}=0.572\end{array}$ & $\begin{array}{c}\mathrm{U}=14953 \\
\mathrm{p}=0.028\end{array}$ & $\begin{array}{c}\mathrm{U}=22207.5 \\
\mathrm{p}=0.668\end{array}$ & $\begin{array}{c}\mathrm{U}=15238.5 \\
\mathrm{p}=0.052\end{array}$ & $\begin{array}{c}\mathrm{U}=22680.5 \\
\mathrm{p}=0.953\end{array}$ \\
\hline Year of the degree & $\begin{array}{c}\chi^{2}=18.218 \\
\mathbf{p}=\mathbf{0 . 0 0 0}\end{array}$ & $\begin{array}{l}\chi^{2}=7.787 \\
\mathbf{p}=\mathbf{0 . 0 2 0}\end{array}$ & $\begin{array}{c}\chi^{2}=17.292 \\
\mathbf{p}=\mathbf{0 . 0 0 0}\end{array}$ & $\begin{array}{l}\chi^{2}=6.102 \\
p=0.047\end{array}$ & $\begin{array}{l}\chi^{2}=0.988 \\
\mathrm{p}=0.638\end{array}$ & $\begin{array}{l}\chi^{2}=1.864 \\
p=0.394\end{array}$ & $\begin{array}{l}\chi^{2}=5.214 \\
p=0.074\end{array}$ & $\begin{array}{l}\chi^{2}=2.064 \\
p=0.356\end{array}$ \\
\hline $\begin{array}{l}\text { Joined hazing } \\
\text { activities in general }\end{array}$ & $\begin{array}{c}\chi^{2}=38.967 \\
\mathbf{p}=\mathbf{0 . 0 0 0}\end{array}$ & $\begin{array}{c}\chi^{2}=27.767 \\
\mathbf{p}=\mathbf{0 . 0 0 0}\end{array}$ & $\begin{array}{c}\chi^{2}=27.593 \\
\mathbf{p}=\mathbf{0 . 0 0 0}\end{array}$ & $\begin{array}{l}\chi^{2}=8.267 \\
\mathbf{p}=\mathbf{0 . 0 1 6}\end{array}$ & $\begin{array}{c}\chi^{2}=127.361 \\
\mathbf{p}=\mathbf{0 . 0 0 0}\end{array}$ & $\begin{array}{c}\chi^{2}=51.659 \\
\mathbf{p}=\mathbf{0 . 0 0 0}\end{array}$ & $\begin{array}{c}\chi^{2}=61.914 \\
\mathbf{p}=\mathbf{0 . 0 0 0}\end{array}$ & $\begin{array}{c}\chi^{2}=23.960 \\
\mathbf{p}=0.000\end{array}$ \\
\hline $\begin{array}{l}\text { Joined hazing activities } \\
\text { in current school year }\end{array}$ & $\begin{array}{c}U=965 \\
p=0.000\end{array}$ & $\begin{array}{c}U=1536.5 \\
p=0.000\end{array}$ & $\begin{array}{l}U=1133 \\
p=0.000\end{array}$ & $\begin{array}{l}\mathrm{U}=2140 \\
\mathrm{p}=0.171\end{array}$ & $\begin{array}{l}\mathrm{U}=5831 \\
\mathrm{p}=0.000\end{array}$ & $\begin{array}{c}\mathrm{U}=11866.5 \\
\mathrm{p}=0.000\end{array}$ & $\begin{array}{l}\mathrm{U}=9241.5 \\
\mathrm{p}=0.000\end{array}$ & $\begin{array}{c}\mathrm{U}=15143.5 \\
\mathrm{p}=0.000\end{array}$ \\
\hline
\end{tabular}

Observing the findings for each institution, we can conclude that the differentiating variables of the relationship with hazing do not coincide. For example, while the year attended by the ESSP students always exhibits significant differences, with $3^{\text {rd }}$-year students denoting a greater attachment to hazing, that variable does not play a distinguishing role at the UAC. The variable gender also displays significant differences in the global scale at the ESSP in the positive and negative relationship with hazing, with boys scoring higher, but it has no differentiating value at the UAC. Behavioural variables are the ones that showcase a more similar trend, with joined hazing activities in general coming in first followed by joined this year. That is, engagement in hazing practices, in general, and participation in these rituals during the current academic year are variables that distinguish students within each institution. The findings for the ESSP lead us to rethink the previous interpretation of students having fun with hazing, at least, in a general perspective. Considering that $3^{\text {rd }}$ year students and boys are the ones that reveal greater attachment to hazing, one may think that they might be having fun at the expense of freshmen. Students from the UAC have a more detached attitude towards these rituals.

Figures 1 and 2 summarise an analysis of responses to the behavioural factors by participants from the ESSP and the UAC.

Figure 1: Joined hazing activities in general, by institution

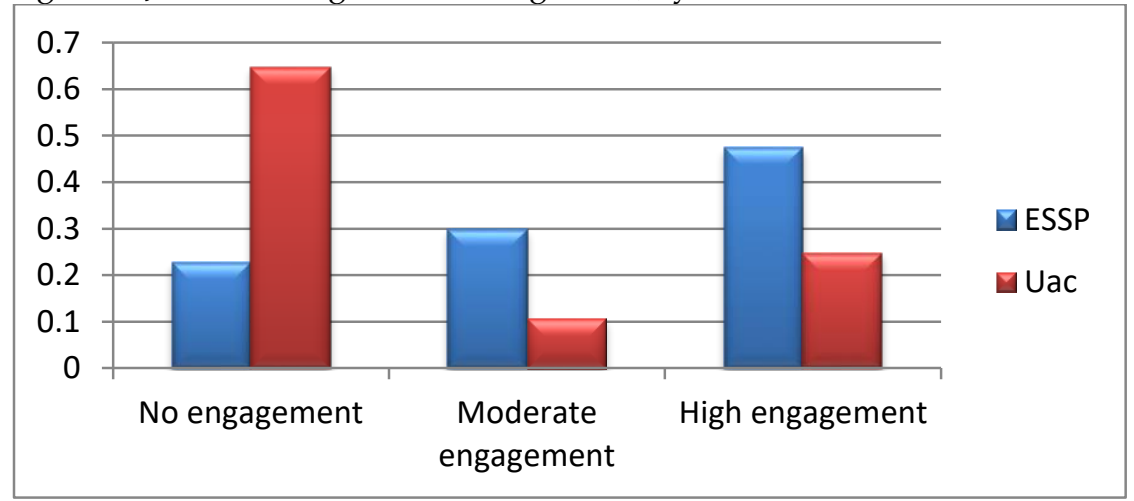


Figure 2: Joined hazing activities in the current school year, by institution

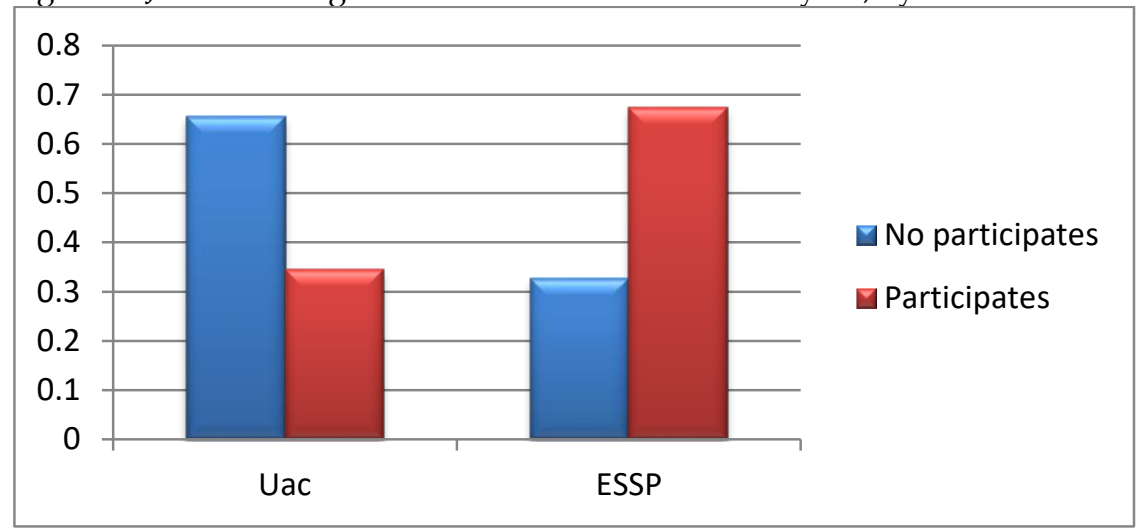

Despite joining hazing activities distinguishing students within each establishment (Table 2), there is evidence of a deeper relationship with hazing at the ESSP, since a high proportion of students from that institution says that they have heavily engaged in hazing activities since they have been at the institution $(47.4 \%)$ and most state that they have participated during the current school year (67.3\%). At the UAC, most students say they have neither engaged in such activities during their stay at the institution $(64.7 \%)$ nor participated during the current year (65.6\%) (Figures 1 and 2). These data explain what we had already inferred about the UAC students' greater detachment from these practices. This event does not captivate students, probably because it has very negative impacts or just because it is not a meaningful and significant phenomenon at the institution.

The graphical representations in the context of the Multiple Correspondence Analysis (MCA) allow us to identify the associations established between the categories of the variables being analysed in order to ascertain the existence (or otherwise) of relatively homogeneous student profiles. Figure 3 illustrates the existence of two dimensions and the plane that crosses them.

Figure 3 - Perceptual map that resulted from the MCA

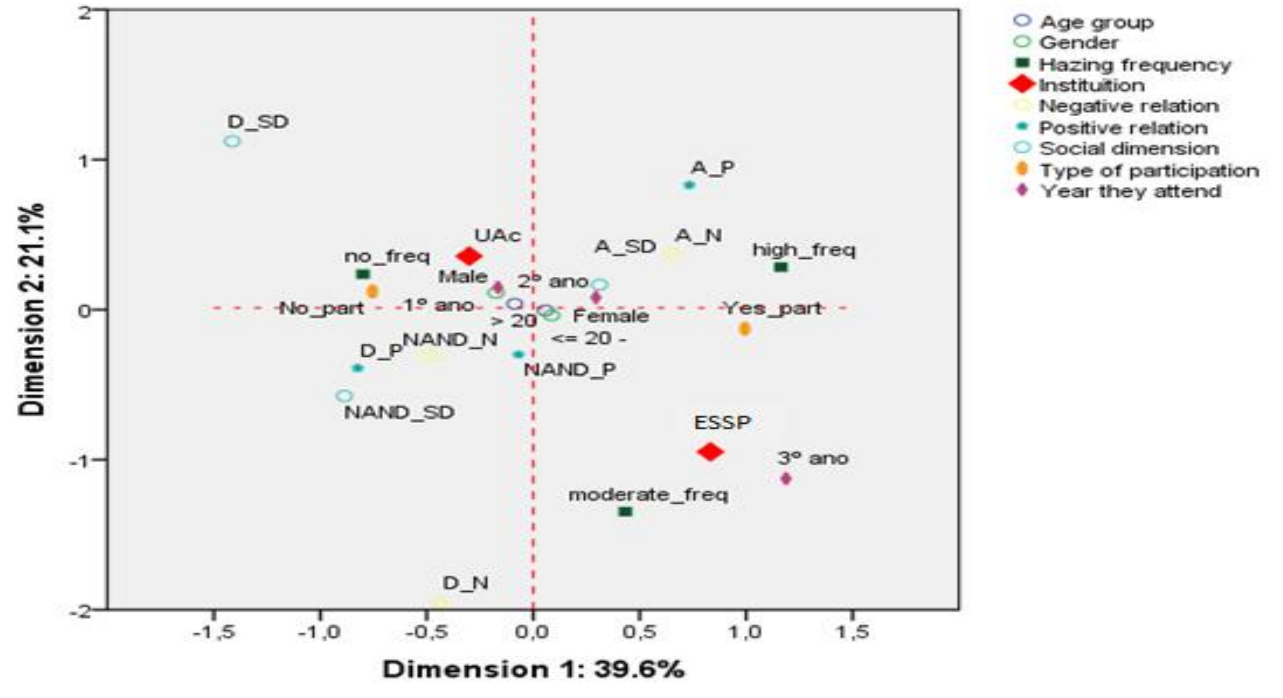

Variable Principal Normalization. 
The first dimension generally opposes students according to behavioural variables, that is, it opposes those that neither engage nor participate in hazing activities to those that do so. The variables joined hazing activities in general, operationalised by the 'level of engagement', and joined hazing activities in the current year, operationalised by the 'level of participation', contribute $28.1 \%$ and $26.3 \%$ respectively to this dimension. The second dimension mainly opposes students from both establishments, with a contribution of $22.4 \%$ to the variable institution. There is also a strong contribution of the variable negative relationship with hazing $(19.4 \%)$ to the second dimension. Viewed together, these first two dimensions explain about $60.7 \%(39.6 \%+21.1 \%)$ of the data variation.

As shown on the perceptual map, ESSP students exhibit a greater interest in engaging in hazing in general and in participating in the activities during the current year, equally expressing a more favourable opinion about hazing. $3^{\text {rd }}$ year students are the ones who claim to have a higher degree of participation in hazing activities. The UAC students are more likely not to join hazing in general, not to participate in these activities in the current year, and to display some indifference towards this ritual and the way they interact with it. At this institution, $1^{\text {st }}$ year students are the ones who declare to have a higher level of participation in these activities.

\section{FinAL Considerations}

In this paper we aimed to determine the type of relationship that students from two Portuguese higher education institutions establish with hazing and whether there are student profiles associated with the different types of relationship with this practice. We have found out that the ESSP students express a more favourable opinion about hazing than their peers from the UAC. At both institutions, the behavioural variable joined hazing differentiates in a statistically significant way the students who neither engage nor participate in hazing from those who participate more often in the various hazing activities, with the ESSP students displaying a deeper relationship with this practice. For the most part, the UAC students do not join hazing activities and denote a certain indifference/apathy towards this academic tradition, which is reflected in the way they relate to hazing. At the ESSP, students who joined hazing are mostly from the $3^{\text {rd }}$ year, while at the UAC they are predominantly from the $1^{\text {st }}$ year. Therefore, we can conclude that students from both institutions have different profiles in what regards their relationship with hazing.

\section{RefERENCES}

Chaleta, M. (2013). Praxes académicas e qualidade da aprendizagem no ensino superior - perspectiva de estudantes de $1^{\circ}$ ano de cursos de licenciatura da Universidade de Évora. Revista Techniques, methodologies and quality $n^{\circ} 4,132$ - 150

Coleyshaw, L. (2010). The power of paradigms: a discussion of the absence of bullying research in the context of the university student experience. Research in Post-Compulsory Education, 15:4, 377-386, DOI: 10.1080/13596748.2010.526799 Acessed: Biblioteca do conhecimento online UAC

DiÁRIO DIGITAL/LUSA. ESTUDANTES DE BRAGANÇA FAZEM DA PRAXE SOLIDARIEDADE PORTA A PORTA (2015). DiÁRIO DIGITAL. HTTP:/ /DIARIODIGITAL.SAPO.PT/NEWS.ASP?ID_NEWS=795157

Dias, D. \& Sá, M. (2013). Rituais de transição no ensino superior português: A praxe enquanto processo de reconfiguração identitária. Revista Galego-Portuguesa de Psicoloxía e Educación. Vol. 21:1, Ano 18 ${ }^{\circ}$, ISSN: 1138-1663. Available from: http://ruc.udc.es/bitstream/2183/12618/1/RGP_21_2013_art_2.pdf

Hazing Prevention Organization. (2015). Hazing and bullying. http://hazingprevention.org/home/ hazing/hazing-and-bullying/ 
Hoover, N. \& Pollard, N. (2000). Initiation rites in American high schools: A national survey. Final Report. New York: Alfred University. Available from: http:/ / files.eric.ed.gov/fulltext/ED445809.pdf

Keating, C., Pomerantz, J., Pommer, S., Ritt, S., Miller, L.\& McCormick, J.(2005). Going to College and Unpacking Hazing: A Functional Approach to Decrypting Initiation Practices Among Undergraduates. Educational Publishing Foundation, 9: 2, 104-130. DOI:10.1037/1089-2699.9.2.104. Available from: http://departments.colgate.edu/psychology/web/keating/JournalArticles/GoingtoCollege.pdf

Klerk, V. (2013). Initiation, Hazing or Orientation? A case study at a south african university. International Research in Education, 1 (1), pp.86-100. Available from: http:/ /dx.doi.org/10.5296/ire.v1i1.4026

Marcitllach, A. \& Freire, A. (2013). Las novatadas: un problema de todos. Revista hispanoamericana Razón y Fe, t. 268, $\mathrm{n}^{\mathrm{o}}$ 1380, 289-298, ISSN 0034-0235. Available from file:/ / C:/Users/PCUser/Downloads/05_AnaAIZPUN.pdf

Mascarenhas, S., Matos, F., Jesus, S., \& Galdino, Z. (n.d.). Diagnóstico e avaliação das praxes ou trotes Um estudo transcultural com universitários de Portugal e do Brasil. Disponível em: http://portal.metodista.br/metodista.br/ev/psicologia-da-saude/anais1/2011/comunicacaooral /co22/TEXTO\%20INTEGRAL\%20\%20Escala\%20Para\%20Avaliacao\%20Das\%20Situacoes\%20De \%20Bullying\%20Nos\%20Trotes\%20Do\%20Ensino\%20Superior\%20Ap.pdf/view

Vieira, P. (2013). Vivências da praxe académica: percepção de integração e ansiedade na transição para o ensino superior. Dissertação de Mestrado em Psicologia da Educação, Desenvolvimento e Aconselhamento. Universidade de Coimbra. Coimbra. 
Publish Online and Print Version Both

Online ISSN: 2312-2021

Google Scholar: https://goo.gl/eozEWi 